\title{
Smartphones as an Opportunity to Increase Sales in Brick-and-Mortar Stores: Identifying Sales Influencers Based on a Literature Review
}

\author{
Robert Zimmermann ${ }^{1(\bowtie)}$, Andreas Auinger ${ }^{1}$, and René Riedl ${ }^{1,2}$ \\ ${ }^{1}$ University of Applied Sciences Upper Austria, Steyr, Austria \\ \{robert. zimmermann, andreas. auinger, \\ rene.riedl\}@fh-steyr.at \\ 2 Johannes Kepler University, Linz, Austria \\ rene.riedl@jku.at
}

\begin{abstract}
The increasing popularity of smartphones, the constant rise of e-commerce turnover and plungingdepartment storesales have a significant impact on brick-and-mortar stores revenue. Nevertheless, brick-and-mortar revenue still makes up $90 \%$ of total retail revenue. This gives rise to the question of how smartphones affect sales in brick-and-mortar stores. In order to investigate the impact of smartphones on brick-and-mortar store sales, this article presents the results of a literature review, summarizing statements about the impact of smartphones on brick-and-mortar store sales into sales influencers. These sales influencerswere categorized into three main types of sales drivers, namely: Utilitarian drivers, cost and time reduction drivers and hedonic drivers. Subsequently, the categorized statements were evaluated according to their potential positive or negative influence on sales. The resulting overview provides information about the current status of research in the field of smartphones as sales influencers in brick-and-mortar stores. It reveals extensively as well as partially researched sales influencers. Hence, the overview also acts as call for future research, encouraging research progression in the field of smartphone influenced sales in brick-and-mortar stores. It can be concluded that, according to the current literature, smartphones have the potential to increase sales in brick-and-mortar stores. However, the variety of sales influencers identified suggests that research is scattered. Hence, future research is needed to analyse how strongly each individual sales influencer affects sales in brick-and-mortar stores.
\end{abstract}

Keywords: Smartphone $\cdot$ Brick-and-mortar stores $\cdot$ Sales

\section{Introduction}

By the year 2018 the smartphone has become part of the everyday lives of 2.6 billion people [1]. E-commerce revenue of 2018 grew 15\% worldwide compared to 2017 summing up to $€ 1,617,053$ million [2] from which $63.5 \%$ were made through mobile retail [3]. In comparison, department store revenue peaked in 2001 and plunged by $36 \%$ until 2018 [4-6]. The emergence of the smartphone as an omnipotent device which for example allows for instant information search, social interactions and online

The original version of this chapter was revised: This chapter was mistakenly published as a regular chapter instead of open access. The correction to this chapter is available at https://doi.org/10.1007/978-3-030-22335-9_26

(C) The Author(s) 2019

F. F.-H. Nah and K. Siau (Eds.): HCII 2019, LNCS 11588, pp. 82-98, 2019.

https://doi.org/10.1007/978-3-030-22335-9_6 
shopping [7], made some authors forecast the end of traditional retail [8,9] and even its complete disappearance $[10,11]$. However, business frombrick-and-mortar stores still accounts for $90 \%$ of total retail revenue [12], wherefore it is unlikely to suffer a major decline of importance in the near future. Nevertheless, smartphones are disrupting brick-and-mortar store business. For example, it is argued that showrooming effects can have a strong impact on brick-and-mortar store sales, or that an informed customer will switch from an in-store offer to an online offer as soon as the price is lower (e.g. [13-15]). However, it is also argued thatthe use of smartphones can drive brick-andmortar store sales by providing an augmented personalized customer experience or that mobile payments can lead to a more streamlined and efficient shopping experience [16-19]. To investigate these conflicting arguments we conducted a literature review, which identifies how the use of smartphones in brick-and-mortar stores can affect their sales. Consequently, the guiding research questions of this paper are:

I: Which smartphone-based factors affect sales in brick-and-mortar stores?

II: Where is additional research needed to complement the understanding of smartphone related influence on sales in brick-and-mortar stores?

This literature review is based on the concept of Vom Brocke et al. [20] and accordingly structured in the following way: First, the "Scope" of the literature review is presented, followed by the underlying "Search Process" and a comprehensive "Literature Analysis and Synthesis". Afterwards, the results of the literature analysis and synthesis are "discussed", a concluding call for future research is madeand the "Limitations" of the literature review are outlined. The paper ends with a conclusion.

\section{Literature Review}

\subsection{Scope}

The focus of this literature review is to identify research outcomes of previous studies, which dealt with the use of smartphones in brick-and-mortar stores and their influence on brick-and-mortar store sales. We summarize previous research and present an overview of possible influencers, which influence sales in brick-and-mortar stores. In the context of Vom Brocke et al. [20], we hereby take a neutral perspective, as we collect rather than criticize available literature. The literature review aims at specialist scholars who are looking for future research opportunities and practitioners who want to have an overview of sales enhancing techniques using smartphones in brick-andmortar stores. We give an exhaustive coverage of the literature, as we want to summarize the current status of smartphone based sales enhancing techniques in brick-andmortar stores.

\subsection{Search Process}

To identify literature, which deals with the topic of how to influence sales in brick-andmortar stores with the use of smartphones, the databases DBIS, Science Direct, Business Source Premier and Web of Science were used. All databases were screened using the 
keyword string "(Smartphone* AND (Brick and Mortar) AND Sales)" in all search fields (DBIS: “All Fields"/Science Direct: "Articles with these terms"/Business Source Premier: "TX All Text"/Web of Science: "TS="). Additionally, the timeframe was set to cover the period from 2007 to 2018. This timeframe was chosen because of the significant shift in smartphone technology brought about by the launch of the iPhone in 2007. Also, the database option of including only academic journals was used. The search was executed in November 2018 and revealed the following number of articles per database: DBIS (155), Science Direct (112), Business Source Premier (108), Web of Science (0). Next, the search results were checked for promising titles and if one was identified, the abstract was read to evaluate if the paper contains information about the influence of smartphones on sales in brick-and-mortar stores. When this condition was met, the paper was included in the final set of papers. To discover additional literature the included papers were used in citation mining including forward and backward search bringing the final number of included papers to 26 .

\subsection{Literature Analysis and Synthesis}

Analysis. To analyze the 26 papers, they were screened for statements indicating an influence of smartphones on sales in brick-and-mortar stores. Afterwards, these statements were rated according to whether they propose a positive $(+)$, neutral $(0)$ or negative (-) influence on sales. They were then summarized into multiple sales influencers (SI) to give a more condensed overview of the various possibilities to influence sales in brick-and-mortar stores with the use of smartphones. Additionally, the statements were assigned to three sales drivers (SD), to allow for a top-level overview of their influence on sales in brick-and-mortar stores. The sales drivers are based on shopper values identified by Willems et al. [13] and consequently split up into Utilitarian Drivers (UD), Cost and Time reduction Drivers (CTrD) and Hedonic Drivers (HD). They are described below and their corresponding sales influencers and the underlying statements are presented in Tables 1, 2, 3. Each statement could be assigned to multiple sales influencers if the statement fitted into more than one description. We paraphrased the original statements to give a more condensed summary of information.

Utilitarian Drivers. Utilitarian drivers describe opportunities, which can affect sales by influencing the customer's shopping experience with the use of a smartphone by providing additional product information, the possibility to compare products or the option for personalization or customization.

Cost and Time Reduction Drivers. This category contains all influences on sales, which present their value by either reducing costs or saving time for the customer or the retailer when using a smartphone in a brick-and-mortar store.

Hedonic Drivers. Hedonic drivers affect sales by altering the customer experience with the use of smartphones in brick-and-mortar stores by providing social interactions, additional experiences and the non-shopping related or playful use of phones. 
Table 1. Literature review - utilitarian drivers.

\begin{tabular}{|c|c|}
\hline SalesInfluencer & Utilitarian DriversInfluence - Statement \\
\hline Showrooming & $\begin{array}{l}\text { (-) Young adults use smartphones when bargain hunting. } \\
\text { They try products in-store to make sure they fit properly, then } \\
\text { purchase them online at a lower price [15] }\end{array}$ \\
\hline Retailer App & $\begin{array}{l}\text { (+) Using an app enables retailers to send personalized } \\
\text { promotions, provide in-store navigation and in-store pick up } \\
\text { options, thus enabling retailers to increase sales and cut labor } \\
\text { costs. Perceived ease of use, usefulness and adoption } \\
\text { likelihood are regarded highly by customers [17] }\end{array}$ \\
\hline MobileScanning & $\begin{array}{l}\text { (0) Mobile scanning is not perceived as more enjoyable nor } \\
\text { as having a greater utilitarian benefit compared to fixed } \\
\text { scanning. The authors also found that mobile unassisted } \\
\text { scanning with a fixed unassisted checkout was a preferred } \\
\text { service mode, while there was evidence that mobile assisted } \\
\text { scanning with mobile assisted payment was the least } \\
\text { preferred checkout mode [21] }\end{array}$ \\
\hline Personalized Mobile Coupons & $\begin{array}{l}\text { (+) Personalized coupons sent to mobile phones which offer } \\
\text { price reductions lead to an increase in-store revenue [22] } \\
(+) \text { Mobile coupons based on a personalized shopping list that } \\
\text { require shoppers to travel farther from their planned path } \\
\text { result in a substantial increase in unplanned spending } \\
\text { compared to coupons for an unplanned category near their } \\
\text { planned path [23] }\end{array}$ \\
\hline Personalized Offers & $\begin{array}{l}\text { (+) Exclusive offers for customers based on their previous } \\
\text { purchase behavior have limited positive impact on the } \\
\text { purchase decision [24] }\end{array}$ \\
\hline LocationTargetedMobile Ads & $\begin{array}{l}\text { (+) Product ads received close to the actual product have an } \\
\text { high impact on the purchase decision [24] }\end{array}$ \\
\hline Location Based Information & $\begin{array}{l}\text { (0) Location based information services are perceived as } \\
\text { useful by customers [25] }\end{array}$ \\
\hline $\begin{array}{l}\text { Information Search Differences } \\
\text { by Product Type }\end{array}$ & $\begin{array}{l}\text { (0) High involvement product categories attract higher } \\
\text { smartphone use for decision support in retail [16] }\end{array}$ \\
\hline $\begin{array}{l}\text { Information Search Differences } \\
\text { by Gender }\end{array}$ & $\begin{array}{l}\text { (0) Young adult men have a significantly higher tendency } \\
\text { than young adult women to conduct smartphone searches for } \\
\text { product information and price of electronics. Young adult } \\
\text { women ask for advice regarding clothing with their } \\
\text { smartphone significantly more often than young adult } \\
\text { men [16] }\end{array}$ \\
\hline In-StoreGuidance & $\begin{array}{l}\text { (+) Providing customers with a personalized shopping route } \\
\text { based on their shopping list can lead to an increase in brick- } \\
\text { and-mortar revenue if the provided route is optimized by } \\
\text { incorporating customers previous shopping behavior [22] } \\
(+) \text { If consumers using smartphones are presented a hyper } \\
\text { relevant shopping experience through "In-Store Guidance" } \\
\text { retailers can capture millions in extra revenue [18] }\end{array}$ \\
\hline
\end{tabular}


Table 1. (continued)

\begin{tabular}{l|l}
\hline SalesInfluencer & Utilitarian DriversInfluence - Statement \\
\hline Location Based Promotions & $\begin{array}{l}\text { (-) The majority of customers do not like to be bothered with } \\
\text { location based promotions [26] }\end{array}$ \\
\hline InformationSearch & $\begin{array}{l}\text { (-) Consumers using mobile technology in a shopping related } \\
\text { purchase more planned items [27] } \\
\text { (-) Young adults use their smartphone to obtain information } \\
\text { about their desired products which makes them feel more } \\
\text { knowledgeable and competent, to the point where they feel } \\
\text { they have more knowledge about products than the shop } \\
\text { assistants. This allows them to challenge the "sales pitch," and } \\
\text { empowers them in their relationships with retailers [15] } \\
\text { (-) Using mobile phones in a task related manner leads to } \\
\text { fewer unplanned purchases [28] } \\
\text { (0) Consumers recognize differences in online and offline } \\
\text { prices which influences their evaluation of the shop's price } \\
\text { competence, their trust in the shop and their patronage of } \\
\text { it [29] }\end{array}$
\end{tabular}

(+) Shopping related mobile phone use causes consumers to become distracted from their shopping task. Once distracted, they spend more time in the store, attend to shelf information more, and divert from their normal path more often, which ultimately increases the amount they purchase. This effect gets stronger with increasing customer age [30]

(+) Mobile devices connected to inventory management can be used by staff to reduce stock outs and also to inform the customer about in-store stock levels, therefore, improve customer experience and leads to an increase in sales [31] (+) Providing customers with local information such as item availability at a nearby store or local store hours, fills in information gaps that keep consumers away from stores [7] (+) Mobile technology provides customers with increased access to information about product, location, special events and promotions which keeps them from looking elsewhere and makes them stay in-store, thus increasing in-store sales [31]

(+) The more searching consumers do on their phones, the more they experience an increase in perceived control over the buying process, which fosters their purchase intention [32]

\begin{tabular}{l|l}
\hline $\begin{array}{l}\text { Location Targeted Mobile } \\
\text { Coupons }\end{array}$ & $\begin{array}{l}\text { (+) Location of mobile coupon delivery significantly } \\
\text { influences redemption rate - the closer the more redemptions } \\
{[33]}\end{array}$ \\
\hline $\begin{array}{l}\text { Customized Mobile Coupon } \\
\text { Expiry Length }\end{array}$ & $\begin{array}{l}\text { (+) Expiry length influences the redemption rate of mobile } \\
\text { coupons - the shorter the more redemptions [33] }\end{array}$ \\
\hline $\begin{array}{l}\text { Customized MobileCoupon } \\
\text { Delivery Day }\end{array}$ & $\begin{array}{l}\text { (+) Day of the week affects mobile coupon redemption rate - } \\
\text { Monday and Tuesday morning having the highest impact } \\
{[33]}\end{array}$
\end{tabular}


Table 1. (continued)

\begin{tabular}{l|l}
\hline SalesInfluencer & Utilitarian DriversInfluence - Statement \\
\hline $\begin{array}{l}\text { Competitive Locational } \\
\text { Coupon Targeting }\end{array}$ & $\begin{array}{l}\text { (+) Competitive locational targeting produced increasing } \\
\text { returns to promotional discount [34] }\end{array}$ \\
\hline $\begin{array}{l}\text { Coupons Locational Targeting } \\
\text { own Retail Store }\end{array}$ & $\begin{array}{l}\text { (-) Targeting retailers' own location produced decreasing } \\
\text { returns to discounts, indicating saturation effects and profit } \\
\text { cannibalization [34] }\end{array}$ \\
\hline Proximity Marketing & $\begin{array}{l}\text { (0) Using proximity marketing enables retailers to send } \\
\text { personalized real time promotions, thus enabling retailers to } \\
\text { increase redemptions of proximity offers. Perceived ease of } \\
\text { use and usefulness are regarded highly by customers. } \\
\text { Nevertheless adoption likelihood is only average [17] }\end{array}$ \\
\hline Product Recommendations & $\begin{array}{l}\text { (+) If consumers using smartphones are presented a hyper } \\
\text { relevant shopping experience through "Product } \\
\text { Recommendations" retailers can capture millions in extra } \\
\text { revenue [18] }\end{array}$ \\
\hline ReadingReviews & $\begin{array}{l}\text { (+) If consumers using smartphones are presented a hyper } \\
\text { relevant shopping experience through "Reviews" retailers } \\
\text { can capture millions in extra revenue [18] }\end{array}$ \\
\hline Mobile Recommendation & $\begin{array}{l}\text { (+) Mobile Recommendation Agents (MRA) and } \\
\text { corresponding infrastructures might increase the sales } \\
\text { volume of retail stores through an increase of consumer } \\
\text { frequency - predicted by consumers' intention to prefer } \\
\text { MRA-enabled retail stores - and the potential of product } \\
\text { purchases - predicted by the consumers' intention to } \\
\text { purchase a product after using the MRA [35] }\end{array}$ \\
\hline
\end{tabular}

Synthesis. Looking at each individual paper, 20 dealt with utilitarian drivers, 14 with cost and time reduction drivers and 12 with hedonic drivers. The papers stretched along the following timeline: No paper published in 2007, in the years 2008-2013 one paper a year, in the years 2014 and 2015 four papers each, in 2016 two papers, in the year 2017 seven papers and in the year 2018 four papers were published.

From the 26 papers included in this literature review we could extract 56 statements about the influence of smartphones on sales in brick-and-mortar stores, of which 39 presented a positive, 8 a neutral and 9 a negative influence on sales in brick-and-mortar stores. Most statements belonged to the category of utilitarian drivers (total: 31/negative: 6/neutral 6/positive 19), followed by cost and time reduction drivers (total: 25/negative: 5/neutral 1/positive 19) and hedonic drivers (total: 23/negative: $2 /$ neutral 3/positive 18) (see also Fig. 1).

The 56 statements were condensed into 29 sales influencers. The number of papers dealing with each individual sales influencer as well as each paper's predicted influence regarding sales in brick-and-mortar stores can be seen in Table 4. 
Table 2. Literature review - cost and time reduction drivers.

\begin{tabular}{|c|c|}
\hline SalesInfluencer & Cost and Time reduction DriversInfluence - Statement \\
\hline Showrooming & $\begin{array}{l}\text { (-) Showrooming decreases profit for online and offline } \\
\text { retailers [14] } \\
\text { (-) Showrooming enhances price competition, leading to } \\
\text { lower profits [13] } \\
\text { (-) Young adults use smartphones when bargain hunting. } \\
\text { They try products in-store to make sure they fit properly, } \\
\text { then purchase them online at a lower price [15] }\end{array}$ \\
\hline MobileCoupons & $\begin{array}{l}\text { (+) Mobile coupons work as a value driver for stores though } \\
\text { their impact on the purchase decision is limited [24] }\end{array}$ \\
\hline $\begin{array}{l}\text { Face Value of } \\
\text { MobileCoupons }\end{array}$ & (+) Face value dominates m-coupon effectiveness [33] \\
\hline $\begin{array}{l}\text { Product Type Customized } \\
\text { MobileCoupons }\end{array}$ & $\begin{array}{l}\text { (+) Product type influences mobile coupon effectiveness - } \\
\text { the cheaper the product the more redemptions [33] }\end{array}$ \\
\hline ScanandPay & $\begin{array}{l}\text { (+) Using Scan and Pay enables retailers to reduce the } \\
\text { number of cashiers and customer waiting time, thus } \\
\text { enabling retailers to cut costs and improve customer } \\
\text { experience. Perceived ease of use, usefulness and adoption } \\
\text { likelihood are regarded high by customers [17] } \\
\text { (+) Mobile check out increases both customer service levels } \\
\text { (in terms of speeding up the process) as well as retailer } \\
\text { internal performance [36] }\end{array}$ \\
\hline MobilePayments & $\begin{array}{l}\text { (+) Mobile Payments can lead to an improvement of } \\
\text { customer experience by simplifying coupon redemption } \\
\text { [31] } \\
\text { (+) Mobile Payments can lead to an improvement of } \\
\text { customer experience by reducing wait times. Mobile } \\
\text { Payment reduces counters in brick-and-mortar stores freeing } \\
\text { up floor space for more productive use [31] }\end{array}$ \\
\hline Retailer App & $\begin{array}{l}\text { (+) App users on average save } 60 \mathrm{~s} \text { while shopping. } \\
\text { Purchasing time for app users is stable throughout the day, } \\
\text { even in the presence of queues during morning and } \\
\text { afternoon rush hours [19] } \\
\text { (+) Using an app enables retailers to send personalized } \\
\text { promotions, provide in-store navigation and in-store pick up } \\
\text { options, thus enabling retailers to increase sales and cut labor } \\
\text { costs. Perceived ease of use, usefulness and adoption } \\
\text { likelihood are regarded highly by customers [17] }\end{array}$ \\
\hline Personalized MobileCoupons & $\begin{array}{l}\text { (+) Personalized coupons sent to mobile phones which offer } \\
\text { price reductions lead to an increase in-store revenue [22] } \\
(+) \text { Mobile coupons based on a personalized shopping list } \\
\text { that require shoppers to travel farther from their planned path } \\
\text { result in a substantial increase in unplanned spending } \\
\text { compared to coupons for an unplanned category near their } \\
\text { planned path [23] }\end{array}$ \\
\hline
\end{tabular}


Table 2. (continued)

\begin{tabular}{|c|c|}
\hline SalesInfluencer & Cost and Time reduction DriversInfluence - Statement \\
\hline SpecialOffers & $\begin{array}{l}\text { (+) If consumers using smartphones are presented a hyper } \\
\text { relevant shopping experience through "Special Offers" } \\
\text { retailers can capture millions in extra revenue [18] }\end{array}$ \\
\hline Personalized Offers & $\begin{array}{l}\text { (+) If consumers using smartphones are presented a hyper } \\
\text { relevant shopping experience through "Targeted Offers" } \\
\text { retailers can capture millions in extra revenue [18] } \\
\text { (+) Exclusive offers for customers based on their previous } \\
\text { purchase behavior have limited positive impact on the } \\
\text { purchase decision [24] }\end{array}$ \\
\hline Information Search & $\begin{array}{l}\text { (+) Mobile technology provides customers with increased } \\
\text { access to information about product, location, special events } \\
\text { and promotions which keeps them from looking elsewhere } \\
\text { and makes them stay in-store, thus increasing in-store sales } \\
\text { [31] }\end{array}$ \\
\hline Location Based Promotions & $\begin{array}{l}\text { (-) The majority of customers do not like to be bothered } \\
\text { with location based promotions [26] }\end{array}$ \\
\hline $\begin{array}{l}\text { Location Targeted Mobile } \\
\text { Coupons }\end{array}$ & $\begin{array}{l}\text { (+) Location of mobile coupon delivery significantly } \\
\text { influences redemption rate - the closer the more } \\
\text { redemptions [33] }\end{array}$ \\
\hline $\begin{array}{l}\text { Customized Mobile Coupon } \\
\text { Expiry Length }\end{array}$ & $\begin{array}{l}\text { (+) Expiry length influences the redemption rate of mobile } \\
\text { coupons - the shorter the more redemptions [33] }\end{array}$ \\
\hline $\begin{array}{l}\text { Customized MobileCoupon } \\
\text { Delivery Day }\end{array}$ & $\begin{array}{l}\text { (+) Day of the week affects mobile coupon redemption rate - } \\
\text { Monday and Tuesday morning having the highest impact } \\
\text { [33] }\end{array}$ \\
\hline $\begin{array}{l}\text { Competitive Locational } \\
\text { Coupon Targeting }\end{array}$ & $\begin{array}{l}\text { (+) Competitive locational targeting produced increasing } \\
\text { returns to promotional discount [34] }\end{array}$ \\
\hline $\begin{array}{l}\text { Coupons Locational Targeting } \\
\text { own Retail Store }\end{array}$ & $\begin{array}{l}\text { (-) Targeting retailers' own location produced decreasing } \\
\text { returns to discounts, indicating saturation effects and profit } \\
\text { cannibalization [34] }\end{array}$ \\
\hline Proximity Marketing & $\begin{array}{l}\text { (0) Using proximity marketing enables retailers to send } \\
\text { personalized real time promotions, thus enabling retailers to } \\
\text { increase redemptions of proximity offers. Perceived ease of } \\
\text { use and usefulness are regarded highly by customers. } \\
\text { Nevertheless adoption likelihood is only average [17] }\end{array}$ \\
\hline
\end{tabular}

Most papers $(8 / 26=31 \%)$ conducted research about the sales influencer "Information Search". "Mobile Payment" was the second most covered sales influencer $(5 / 26=19 \%)$. The sales influencers "Showrooming", "Distraction", "Scan and Pay" and "Personalized Mobile Coupons" were covered by three papers each $(3 / 26=12 \%)$. The rest of the sales influencers were covered by either two (4 sales influencers; $7.7 \%$ ) or one paper (19 sales influencers; 3.8\%). 
Table 3. Literature review - hedonic drivers.

\begin{tabular}{|c|c|}
\hline SalesInfluencer & Hedonic DriversInfluence - Statement \\
\hline Showrooming & $\begin{array}{l}\text { (-) Young adults use smartphones when bargain hunting. They try } \\
\text { products in-store to make sure they fit properly, then purchase them } \\
\text { online at a lower price [15] }\end{array}$ \\
\hline Scan and Pay & $\begin{array}{l}\text { (+) If consumers using smartphones are presented a hyper relevant } \\
\text { shopping experience through "Scan and Pay" retailers can capture } \\
\text { millions in extra revenue [18] }\end{array}$ \\
\hline MobilePayments & $\begin{array}{l}\text { (0) Mobile payment scenarios do not entail greater privacy concerns } \\
\text { compared to fixed payment [21] } \\
\text { (+) If consumers using smartphones are presented a hyper relevant } \\
\text { shopping experience through "Mobile Payments" retailers can capture } \\
\text { millions in extra revenue [18] } \\
\text { (+) Mobile payment, as an innovative payment option, leads to more } \\
\text { positive overall price image judgments by customers, which } \\
\text { contributes to a greater store loyalty [37] } \\
\text { (+) Mobile payment significantly increases customers' willingness to } \\
\text { pay when compared to cash payments [37] } \\
(+) \text { All interviewed merchants view enhancement of the customer } \\
\text { shopping experience as a primary benefit of mobile payments, } \\
\text { although some are concerned their customers may find mobile } \\
\text { commerce or payment applications burdensome or complex [38] }\end{array}$ \\
\hline Retailer App & $\begin{array}{l}\text { (+) Using an app enables retailers to send personalized promotions, } \\
\text { provide in-store navigation and in-store pick up options, thus } \\
\text { enabling retailers to increase sales and cut labor costs. Perceived ease } \\
\text { of use, usefulness and adoption likelihood are regarded highly by } \\
\text { customers [17] }\end{array}$ \\
\hline MobileScanning & $\begin{array}{l}\text { (+) If consumers using smartphones are presented a hyper relevant } \\
\text { shopping experience through "Scan QR Code" retailers can capture } \\
\text { millions in extra revenue [18] } \\
\text { (0) Mobile scanning is not perceived as more enjoyable nor as having } \\
\text { a greater utilitarian benefit compared to fixed scanning. The authors } \\
\text { also argue that mobile unassisted scanning with a fixed unassisted } \\
\text { checkout was a preferred service mode, while there was evidence that } \\
\text { mobile assisted scanning with mobile assisted payment was the least } \\
\text { preferred checkout mode [21] }\end{array}$ \\
\hline SocialSharing & $\begin{array}{l}\text { (0) Young adults use smartphones to ask for advice and feedback } \\
\text { concerning their planned in-store purchases using their social media } \\
\text { channels [15] }\end{array}$ \\
\hline Distraction & $\begin{array}{l}\text { (-) The non-shopping related use of mobile technology negatively } \\
\text { impacts shoppers' ability to recall in-store stimuli [27] } \\
\text { (+) Non-shopping related use of smartphones causes consumers to } \\
\text { become distracted from their shopping task. Once distracted, they } \\
\text { spend more time in the store, attend to shelf information more, and } \\
\text { divert from their normal path more often, which ultimately increases } \\
\text { the amount they purchase. This effect gets stronger with increasing } \\
\text { customer age. This effect is also present but not as strong in shopping } \\
\text { related smartphone use [30] } \\
(+) \text { Using mobile phones in a task unrelated manner leads to more } \\
\text { unplanned purchases [28] }\end{array}$ \\
\hline
\end{tabular}


Table 3. (continued)

\begin{tabular}{l|l}
\hline SalesInfluencer & Hedonic DriversInfluence - Statement \\
\hline $\begin{array}{l}\text { Personalized Mobile } \\
\text { Coupons }\end{array}$ & $\begin{array}{l}\text { (+) Task unrelated device use plays in consumers' reliance on in-store } \\
\text { signage and promotion signals during decision-making [28] } \\
\text { provide personalized coupons and exclusive offers [7] }\end{array}$ \\
\hline SpecialOffers & $\begin{array}{l}\text { (+) If consumers using smartphones are presented a hyper relevant } \\
\text { shopping experience through "Special Offers" retailers can capture } \\
\text { millions in extra revenue [18] }\end{array}$ \\
\hline Personalized Offers & $\begin{array}{l}\text { (+) If consumers using smartphones are presented a hyper relevant } \\
\text { shopping experience through "Targeted Offers" retailers can capture } \\
\text { millions in extra revenue [18] }\end{array}$ \\
\hline Information Search & $\begin{array}{l}\text { (+) The more searching consumers do on their phones, the more they } \\
\text { experience an increase in perceived control over the buying process, } \\
\text { which fosters their purchase intention [32] }\end{array}$ \\
\hline $\begin{array}{l}\text { In-StoreGuidance } \\
\text { (+) If consumers using smartphones are presented a hyper relevant } \\
\text { shopping experience through "In-Store Guidance" retailers can } \\
\text { capture millions in extra revenue [18] }\end{array}$ \\
\hline $\begin{array}{l}\text { Product } \\
\text { Recommendations } \\
\text { shopping experience through "Product Recommendations" retailers } \\
\text { can capture millions in extra revenue [18] }\end{array}$ \\
\hline $\begin{array}{l}\text { Recommendation } \\
\text { Agent }\end{array}$ & $\begin{array}{l}\text { shopping experience through "Reviews" retailers can capture } \\
\text { millions in extra revenue [18] }\end{array}$ \\
\hline $\begin{array}{l}\text { (+) Mobile Recommendation Agents (MRA) and corresponding } \\
\text { infrastructures might increase the sales volume of retail stores } \\
\text { through an increase of consumer frequency - predicted by } \\
\text { consumers' intention to prefer MRA-enabled retail stores - and the } \\
\text { potential of product purchases - predicted by the consumers' } \\
\text { intention to purchase a product after using the MRA [35] }\end{array}$ \\
\hline Mobile
\end{tabular}

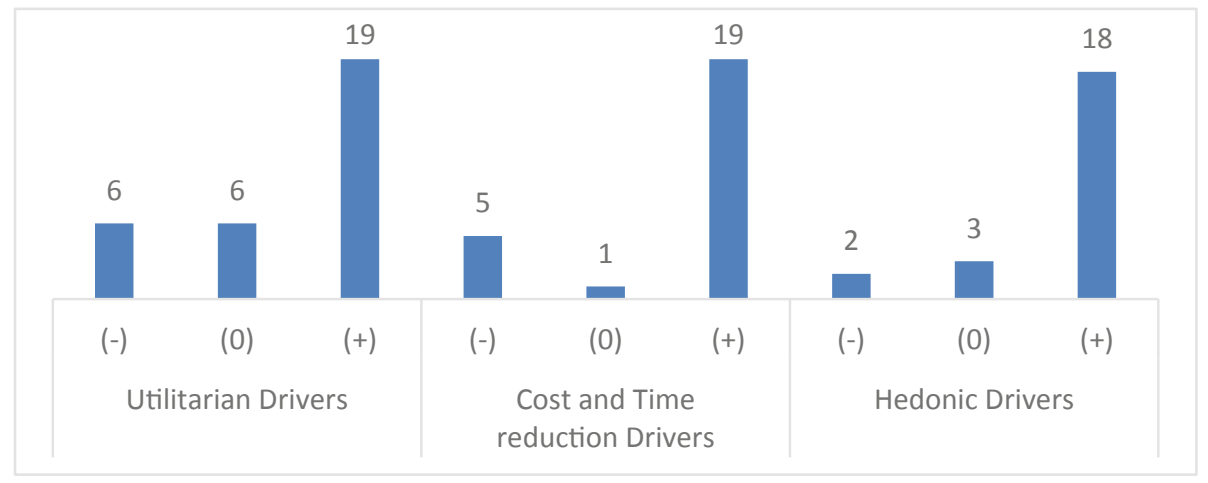

Fig. 1. Descriptive results of literature review - statements 
Table 4. Overview sales influencer.

\begin{tabular}{|c|c|c|c|c|c|c|c|}
\hline SI & $\begin{array}{l}\sum \mathrm{UD} \\
\text { statements }\end{array}$ & $\sum_{\text {UD P. }}$ & $\begin{array}{l}\sum \mathrm{CTrD} \\
\text { statements }\end{array}$ & $\sum_{\mathrm{CTrD} P .}$ & $\sum_{\text {statements }} \mathrm{HD}$ & $\begin{array}{l}\sum_{\text {HD P. }} \\
\text { H. }\end{array}$ & $\begin{array}{l}\sum \\
P .\end{array}$ \\
\hline Information Search & $\begin{array}{l}(-) 3[15, \\
27,28] \\
(0) 1[29] \\
(+) 5[7, \\
30-32]\end{array}$ & 8 & $(+) 1[31]$ & 1 & $(+) 1[32]$ & 1 & 8 \\
\hline Mobile Payments & N/A & 0 & $(+) 2[31]$ & 1 & $\begin{array}{l}(0) 1[21] \\
(+) 4[18 \\
37,38]\end{array}$ & 4 & 5 \\
\hline Showrooming & $(-) 1[15]$ & 1 & $\begin{array}{l}(-) 3[13- \\
15]\end{array}$ & 3 & $(-) 1[15]$ & 1 & 3 \\
\hline Distraction & N/A & 0 & N/A & 0 & $\begin{array}{l}(-) 1[27] \\
(+) 3[28, \\
39]\end{array}$ & 3 & 3 \\
\hline Scan and Pay & N/A & 0 & $\begin{array}{l}(+) 2[17, \\
36]\end{array}$ & 2 & $(+) 1[18]$ & 1 & 3 \\
\hline $\begin{array}{l}\text { Personalized Mobile } \\
\text { Coupons }\end{array}$ & $\begin{array}{l}(+) 2[22, \\
23]\end{array}$ & 2 & $\begin{array}{l}(+) 2[22, \\
23]\end{array}$ & 2 & $(+) 1[7]$ & 1 & 3 \\
\hline Mobile Scanning & (0)1[21] & 1 & N/A & 0 & $\begin{array}{l}(0) 1[21] \\
(+) 1[18]\end{array}$ & 2 & 2 \\
\hline In-Store Guidance & $\begin{array}{l}(+) 2[18, \\
22]\end{array}$ & 2 & N/A & 0 & $(+) 1[18]$ & 1 & 2 \\
\hline Retailer App & $(+) 1[17]$ & 1 & $\begin{array}{l}+2[17, \\
19]\end{array}$ & 2 & $(+) 1[17]$ & 1 & 2 \\
\hline Personalized Offers & $(+) 1[24]$ & 1 & $\begin{array}{l}(+) 2[18, \\
24]\end{array}$ & 2 & $(+) 1[18]$ & 1 & 2 \\
\hline $\begin{array}{l}\text { Coupons Locational } \\
\text { Targeting Own Retail } \\
\text { Store }\end{array}$ & $(-) 1[34]$ & 1 & $(-) 1[34]$ & 1 & N/A & 0 & 1 \\
\hline $\begin{array}{l}\text { Location Based } \\
\text { Promotions }\end{array}$ & $(-) 1[26]$ & 1 & $(-) 1[26]$ & 1 & N/A & 0 & 1 \\
\hline $\begin{array}{l}\text { Information Search } \\
\text { Differences by Gender }\end{array}$ & (0)1 [16] & 1 & N/A & 0 & N/A & 0 & 1 \\
\hline $\begin{array}{l}\text { Information Search } \\
\text { Differences by Product } \\
\text { Type }\end{array}$ & (0)1 [16] & 1 & N/A & 0 & N/A & 0 & 1 \\
\hline $\begin{array}{l}\text { Location Based } \\
\text { Information }\end{array}$ & (0)1 [25] & 1 & N/A & 0 & N/A & 0 & 1 \\
\hline Social Sharing & N/A & 0 & N/A & 0 & (0)1 [15] & 1 & 1 \\
\hline $\begin{array}{l}\text { Face Value of Mobile } \\
\text { Coupons }\end{array}$ & N/A & 0 & $(+) 1[33]$ & 1 & N/A & 0 & 1 \\
\hline $\begin{array}{l}\text { Location Targeted Mobile } \\
\text { Ads }\end{array}$ & $(+) 1[24]$ & 1 & N/A & 0 & N/A & 0 & 1 \\
\hline
\end{tabular}


Table 4. (continued)

\begin{tabular}{|c|c|c|c|c|c|c|c|}
\hline SI & $\sum_{\text {statements }}$ UD & $\sum_{\text {UD P. }}$ & $\sum_{\text {statements }} \mathrm{CTrD}$ & $\sum_{\text {CTrD P. }}$ & $\begin{array}{l}\sum_{\text {statements }} \mathrm{HD} \\
\end{array}$ & $\sum_{\text {HD P. }}$ & $\begin{array}{l}\sum \\
P .\end{array}$ \\
\hline Mobile Coupons & N/A & 0 & $(+) 1[24]$ & 1 & N/A & 0 & 1 \\
\hline $\begin{array}{l}\text { Product Type Customized } \\
\text { Mobile Coupons }\end{array}$ & N/A & 0 & $(+) 1[33]$ & 1 & N/A & 0 & 1 \\
\hline $\begin{array}{l}\text { Competitive Locational } \\
\text { Coupon Targeting }\end{array}$ & $(+) 1[34]$ & 1 & $(+) 1[34]$ & 1 & N/A & 0 & 1 \\
\hline $\begin{array}{l}\text { Customized Mobile } \\
\text { Coupon Delivery Day }\end{array}$ & $(+) 1[33]$ & 1 & $(+) 1[33]$ & 1 & N/A & 0 & 1 \\
\hline $\begin{array}{l}\text { Customized Mobile } \\
\text { Coupon Expiry Length }\end{array}$ & $(+) 1[33]$ & 1 & $(+) 1[33]$ & 1 & N/A & 0 & 1 \\
\hline $\begin{array}{l}\text { Location Targeted Mobile } \\
\text { Coupons }\end{array}$ & $(+) 1[33]$ & 1 & $(+) 1[33]$ & 1 & N/A & 0 & 1 \\
\hline $\begin{array}{l}\text { Mobile Recommendation } \\
\text { Agent }\end{array}$ & $(+) 1[35]$ & 1 & N/A & 0 & $(+) 1[35]$ & 1 & 1 \\
\hline $\begin{array}{l}\text { Product } \\
\text { Recommendations }\end{array}$ & $(+) 1[18]$ & 1 & N/A & 0 & $(+) 1[18]$ & 1 & 1 \\
\hline Proximity Marketing & $(+) 1[17]$ & 1 & $(+) 1[17]$ & 1 & N/A & 0 & 1 \\
\hline Reading Reviews & $(+) 1[18]$ & 1 & N/A & 0 & $(+) 1[18]$ & 1 & 1 \\
\hline Special Offers & N/A & 0 & $(+) 1[18]$ & 1 & $(+) 1[18]$ & 1 & 1 \\
\hline
\end{tabular}

\section{Discussion and a Call for Future Research}

\subsection{Discussion}

Looking at the overall results of the literature review we argue that this paper found more evidence that smartphones rather increase than decrease sales in brick-and-mortar stores, as far more positive (38) than negative statements (9) could be identified. However, no prediction can be made about how strongly each individual factor affects sales in brick-and-mortar stores. The research conducted on the various sales influencers is discussed below.

Extensively Researched Sales Influencer. Looking at the sales influencers in detail, only "Information Search" and "Mobile Payment" have been researchedextensively. "Information Search" was mostly analyzed from a utilitarian driver perspective (see Table 4). Additionally, the highest number of positive (5) but also negative statements (3) was found for this sales influencer. Grewal et al. [30] argues that "Information Search" can lead to distraction which makes customers divert from their normal shopping path and increases purchases (this effect gets stronger with increasing customer age). Paul et al. [31] indicate that "Information Search" leads to a more locked in shopping experience which drives sales rate. Rippé et al. [32] reasons that "Information Search" leads to a perceived increase in control which fosters purchase intention. In contrast, Bellini and Aiolfi [27] and Sciandra and Inman [28] claim, that the use of smartphones in a shopping related way leads to fewer planned and unplanned purchases because mobile device use consumes attentional resources and makes in-store communication strategies less effective. Fuentes and Svingstedt [15] argue that young adults who use their smartphone to obtain information become more knowledgeable 
and competent to the point where they can effectively challenge the "sales pitch" of shop assistants which leads to a reduction in revenue. Although "Information Search" is seen as positive, retailers should regard it as an ambivalent sales influencer. On the one hand, information search creates an informed and distracted customer who is locked into a perceived superior purchase experience and therefore buys more. Alternatively, it can lead to an over informed customer who has an increased bargaining power and does not rely on in-store stimuli. According to the reviewed literature, factors like gender, age or product categories are moderators [16]. For example, "Information Search" by younger customers is more likely to have a negative effect on sales whereas information search by older customers leads to an increase in sales. Therefore, it can be concluded, that the sales influencer "Information Search" can be viewed as having a sale enhancing effect on older customers and a sales decreasing effect on younger ones. Papers about "Mobile Payment" focused on a hedonic driver perspective. Six positive statements and one neutral statement could be identified, describing that "Mobile Payments" can enhance shopping experience [18, 31, 37, 38], lead to higher positive price image judgement and therefore store loyalty [37], increase the willingness to pay compared to cash payments [37] and do not inherit greater privacy concerns compared to fixed payment[21]. Therefore, mobile payments seem to have a strong influence on brick-and-mortar store sales rate. Although the sales influencers "Information Search" and "Mobile Payment" were researched by the highest number of papers in the conducted literature review this research focused mainly on one sales driver ("Information Search"/UD; "Mobile Payment"/HD). Therefore, we argue that even for these highly researched sales influencers more research, analyzing the sales drivers not yet covered, is needed to give a more comprehensive overview of their influence on sales.

Moderately Researched Sales Influencers. Moderate research has been carried out for the sales influencers "Showrooming", "Distraction", "Scan and Pay" and "Personalized mobile Coupons". Research about "Showrooming" was mainly conducted from a cost and time reduction perspective. According to literature "Showrooming" has a negative influence on sales as it is generally seen as a technique which decreases profit for retailers by enhancing price competition [13, 15, 27, 28]. However, it can be sale enhancing if it is avoided or mitigated by retailers. To counter "Showrooming" Mehra et al. [5] suggest price matching as a short term solution and an exclusivebrand strategy as a long term solution. Another way would be to cut internet access for instore customers but this would also have an unforeseeable impact on other sales influencers, which rely on an internet connection, wherefore it is not recommended. The sales influencer "Distraction" was analyzed from a hedonic driver perspective only. "Distraction" seems to have a mixed influence on sales. Grewal et al. [30] argue that distraction caused by non-shopping related phone use leads to extra time spent and distance walked in brick-and-mortar stores which ultimately leads to an increase in purchases (this effect gets stronger with increasing customer age). Sciandra and Inman [28] add that these distractions lead to more unplanned purchases and customer's reliance on in-store signage and promotion signals significantly improves. In sharp contrast, Bellini and Aiolfi [27] point out that non shopping related use of mobile technology negatively influences the ability of customers to recall in-store stimuli. Taking into account that according to Fuentes and Svingstedt [15] young adults use smartphones to ask for advice and feedback concerning their planed in-store purchases 
using their social media channels, we argue that young adults are more likely to miss or disregard in-store stimuli as they get distracted by checking their phones for new advice from their peers. Summing it up, the sales influencer "Distraction" is sale enhancing for older customers or customers who do not rely on social advice and feedback and sales diminishing for younger customers or customers who do rely on social advice and feedback. The sales influencer "Scan and Pay" was analyzed mainly from a cost and time reduction perspective. However, one paper also analyzed this aspect from a hedonic driver perspective. As all statements about "Scan and Pay" were positive, and therefore it seems to have a sale enhancing effect. According to literature, this works by enabling retailers to reduce the number of cashiers and customer waiting time, thus enabling retailers to cut costs and improve customer experience. Perceived ease of use, usefulness and adoption likelihood are regarded highly by customers [17]. Additionally, "Scan and Pay" does increase both customer service levels (in terms of speeding up the process) as well as retailer internal performance [36], while also making the shopping experience hyper relevant [18]. "Personalized Mobile Coupons" was mainly researched from a utilitarian driver and cost and time reduction driver perspective, though one paper analyzed it from a hedonic driver perspective. According to literature it positively influences sales in a hedonic way as shoppers prefer shopping in brickand-mortar stores that provide personalized coupons[7], as well as in utilitarian and cost and time saving ways by offering discounts, based on previous shopping behavior, which require shoppers to travel farther through the retail store [22, 23]. Moderate research about the mentioned sales influencers was published and that research focused mainly on analyzing one type of sales driver. Therefore, we argue that more research needs to carried out to cover the non-addressed sales drivers to obtain a deeper understanding of how these factors can influence sales in brick-and-mortar stores.

Partially Researched Sales Influencers. For all not yet mentioned sales influencers only limited research was found, and therefore it is too early to draw conclusions regarding their impact on brick-and-mortar store sales rate. However, for all sales influencers in this category, with the exception of "Coupons Locational Targeting Own Retail Store and "Location Based Promotions", only positive statements about the influence of smartphones on sales in brick-and-mortar stores could be identified. This substantiates the conclusion that smartphones influence sales rather in a positive than a negative way.

Additional Findings. As 20 of the 26 papers analyzed utilitarian drivers and made 31 of the 56 identified statements (6 negative, 6 neutral 19 positive), we observe an imbalance if compared to cost and time reduction (14 papers $/ 25$ statements $/ 5$ negative, 1 neutral, 19 positive) and hedonic drivers (12 papers/23 statements/2 negative, 3 neutral, 18 positive). In the years 2007 to 2013 only little research was carried out, whereas after 2014 the quantity of research increased significantly peaking in 2017 with 7 published papers. This is correlated with the rising importance of smartphones in retail in general $[3,40]$ and the constant growth of e-commerce [2].

\subsection{Call for Future Research}

Future Research Implications. Summarizing the literature review, we conclude that additional research is needed for all identified sales influencers and sales drivers. Even the extensively researched sales influencers "Information Search" and "Mobile 
Payment" have only been examined from either a utilitarian driver or a hedonic driver perspective, whereas even for these sales influencers additional research is needed to better understand their influence on sales in brick-and-mortar stores. Future researchers can use our overview created in Table 4 to identify possible research opportunities for each individual sales influencer. Additionally, we propose that some kind of unifying research is needed which makes it possible to predict the influence of each individual sales influencer on sales in brick-and-mortar stores.

Limitations. Although an extensive literature review with forward and backward search has been conducted, it cannot be guaranteed that all relevant literature has been found. Therefore, while we consider our review as comprehensive, it may not be necessarily exhaustive. In addition, in the present paper we did not take into account all specific store settings, product types, gender implications or other very specific variables. Therefore, one has to be careful when applying results of the extracted statements in different settings.

\section{Conclusion}

This paper raised the questions "Which smartphone-based factors affect sales in brickand-mortar stores?" and "Where is additional research needed to complement the understanding of smartphone related influence on sales in brick-and-mortar stores?". Concerning the first research question, 29 sales influencers, which have an influence on sales in brick-and-mortar stores could be identified in literature. Additionally, we come to the conclusion that, in general, smartphones tend to increase sales in brick-andmortar stores as this paper identified 56 statements from which 39 presented a positive, 8 a neutral and 9 a negative influence on sales. However, as the analyzed papers and their underlying research methods are not comparable we cannot make any prediction on how strongly each individual sales influencer influences sales in brick and mortar stores. Looking at the second research question, we conclude that additional research is needed for every identified sales influencer. This is because either limited research was done for most sales influencers or if the quantity of research was extensive, it was done from one of the three presented sales driver perspectives only.

Acknowledgments. This study has been conducted within the training network project PERFORM funded by the European Union's Horizon 2020 research and innovation program under the Marie Skłodowska-Curie grant agreement No. 76539. Note: This research reflects only the authors' view. The Agency is not responsible for any use that may be made of the information it contains.

\section{References}

1. eMarketer: Smartphone-Nutzer weltweit 2012-2021 | Statista. Prognose zur Anzahl der Smartphone-Nutzer weltweit von 2012 bis 2021 (in Milliarden). https://de.statista.com/ statistik/daten/studie/309656/umfrage/prognose-zur-anzahl-der-smartphone-nutzer-weltweit/. Accessed 6 Dec 2018

2. Statista: eCommerce - worldwide | Statista Market Forecast. https://www.statista.com/ outlook/243/100/ecommerce/worldwide?currency=eur. Accessed 22 Jan 2019 
3. eMarketer and InternetRetailing: Mobile retail commerce sales as percentage of retail ecommerce sales worldwide from 2016 to 2021. https://www.statista.com/statistics/806336/ mobile-retail-commerce-share-worldwide/. Accessed 22 Jan 2019

4. Wolf, R.: Here's which brick-and-mortar retailers are getting hit the hardest. https://www. businessinsider.com/brick-and-mortar-retailers-getting-hit-the-hardest-2018-5?IR=T. Accessed 22 Jan 2019

5. US Census Bureau: Department store sales (excluding leased departments) in the United States from 1992 to 2016 (in billion U.S. dollars). https://www.statista.com/statistics/ 197712/annual-department-store-sales-in-the-us-since-1992/. Accessed 22 Jan 2019

6. ICSC: Sales growth of department stores in Western Europe from 2012 to 2017, by country. https://www.statista.com/statistics/911107/department-store-sales-growth-western-europe/. Accessed 22 Jan 2019

7. Google: Digital Impact on In-Store Shopping: Research Debunks Common Myths. https://think. storage.googleapis.com/docs/digital-impact-on-in-store-shopping_research-studies.pdf.

Accessed 3 Dec 2018

8. Helm, S., Kim, S.H., van Riper, S.: Navigating the 'retail apocalypse': a framework of consumer evaluations of the new retail landscape. J. Retail. Consum. Serv. (2018)

9. Peterson, H.: A tsunami of store closings is about to hit the US - and it's expected to eclipse the retail carnage of 2017. https://www.businessinsider.de/store-closures-in-2018will-eclipse-2017-2018-1?r=US\&IR=T. Accessed 23 Jan 2019

10. Winthrop, B., Komisar, R.: I F**king Love that Company. How a New Generation of Brand Builders is Defining the Post-Amazon world. Paramount Market Publishing, Inc., Ithaca (2015)

11. Townsend, M., Surane, J., Orr, E., Cannon, C.: America's 'Retail Apocalypse' Is Really Just Beginning. https://www.bloomberg.com/graphics/2017-retail-debt/. Accessed 23 Jan 2019

12. Dennis, S.: E-Commerce May Be Only 10\% Of Retail, But That Doesn't Tell The Whole Story. https://www.forbes.com/sites/stevendennis/2018/04/09/e-commerce-fake-news-theonly-10-fallacy/\#22b6767539b4. Accessed 6 Dec 2018

13. Mehra, A., Kumar, S., Raju, J.S.: Competitive strategies for brick-and-mortar stores to counter "showrooming". Manag. Sci. 64, 3076-3090 (2018)

14. Basak, S., Basu, P., Avittathur, B., Sikdar, S.: A game theoretic analysis of multichannel retail in the context of "showrooming". Decis. Support Syst. 103, 34-45 (2017)

15. Fuentes, C., Svingstedt, A.: Mobile phones and the practice of shopping: a study of how young adults use smartphones to shop. J. Retail. Consum. Serv. 38, 137-146 (2017)

16. Eriksson, N., Rosenbröijer, C.-J., Fagerstrøm, A.: Smartphones as decision support in retail stores - the role of product category and gender. Procedia Comput. Sci. 138, 508-515 (2018)

17. Inman, J.J., Nikolova, H.: Shopper-facing retail technology: a retailer adoption decision framework incorporating shopper attitudes and privacy concerns. J. Retail. 93, 7-28 (2017)

18. Bradley, J., Macaulay, J., O’Connell, K., Delaney, K., Pinto, A., Barbier, J.: Winning the New Digital Consumer with Hyper-Relevance. In Retail, Insight Is Currency and Context Is King. https://www.startitup.sk/wp-content/uploads/2015/11/ioe-retail-whitepaper.pdf. Accessed 24 Nov 2018

19. Vuckovac, D., Fritzen, P., Fuchs, K., Ilic, A.: From Shopping aids to fully autonomous mobile self-checkouts - a field study in retail. In: Wirtschaftsinformatik 2017 Proceedings, pp. 927-941 (2017)

20. vom Brocke, J., Simon, A., Niehaves, B., Reimer, K., Plattf, R., Cleven, A.: Reconstructing the giant: on the importance of rigour in documenting the literature search process

21. Aloysius, J.A., Hoehle, H., Venkatesh, V.: Exploiting big data for customer and retailer benefits. Int. J. Oper. Prod. Manag. 36, 467-486 (2016)

22. Klabjan, D., Pei, J.: In-store one-to-one marketing. J. Retail. Consum. Serv. 18, 64-73 (2011) 
23. Hui, S.K., Inman, J.J., Huang, Y., Suher, J.: The effect of in-store travel distance on unplanned spending: applications to mobile promotion strategies. J. Mark. 77, 1-16 (2013)

24. Bues, M., Steiner, M., Stafflage, M., Krafft, M.: How mobile in-store advertising influences purchase intention: value drivers and mediating effects from a consumer perspective. Psychol. Mark. 34, 157-174 (2017)

25. Choi, S.: What promotes smartphone-based mobile commerce? Mobile-specific and selfservice characteristics. Internet Res. 28, 105-122 (2018)

26. Rudolph, T., Bassett, M., Weber, M.: Konsumententrends im Schweizer Lebensmitteldetailhandel (2015)

27. Bellini, S., Aiolfi, S.: The impact of mobile device use on shopper behaviour in store: an empirical research on grocery retailing. IBR 10, 58 (2017)

28. Sciandra, M., Inman, J.: Digital distraction: consumer mobile device use and decision making. SSRN J. (2016)

29. Broeckelmann, P., Groeppel-Klein, A.: Usage of mobile price comparison sites at the point of sale and its influence on consumers' shopping behaviour. Int. Rev. Retail. Distrib. Consum. Res. 18, 149-166 (2008)

30. Grewal, D., Ahlbom, C.-P., Beitelspacher, L., Noble, S.M., Nordfält, J.: In-store mobile phone use and customer shopping behavior: evidence from the field. J. Mark. 82, 102-126 (2018)

31. Paul, A., Asmundson, P., Goswami, D., Mawhinney, T., Nannini, J.: Mobile retailing - are you ready for radical change? (2012)

32. Rippé, C.B., Weisfeld-Spolter, S., Yurova, Y., Dubinsky, A.J., Hale, D.: Under the sway of a mobile device during an in-store shopping experience. Psychol. Mark. 34, 733-752 (2017)

33. Danaher, P.J., Smith, M.S., Ranasinghe, K., Danaher, T.S.: Where, when, and how long: factors that influence the redemption of mobile phone coupons. J. Mark. Res. 52, 710-725 (2015)

34. Fong, N.M., Fang, Z., Luo, X.: Geo-conquesting: competitive locational targeting of mobile promotions. J. Mark. Res. 52, 726-735 (2015)

35. Kowatsch, T., Maass, W.: In-store consumer behavior: how mobile recommendation agents influence usage intentions, product purchases, and store preferences. Comput. Hum. Behav. 26, 697-704 (2010)

36. Andriulo, S., Elia, V., Gnoni, M.G.: Mobile self-checkout systems in the FMCG retail sector. A comparison analysis. Int. J. RF Technol. Res. Appl. 6, 207-224 (2014)

37. Falk, T., Kunz, W.H., Schepers, J.J.L., Mrozek, A.J.: How mobile payment influences the overall store price image. J. Bus. Res. 69, 2417-2423 (2016)

38. Hayashi, F., Bradford, T.: Mobile payments: merchants' perspectives. Econ. Rev. Q II, 33-58 (2014)

39. Grewal, D., Roggeveen, A.L., Nordfält, J.: The future of retailing. J. Retail. 93, 1-6 (2017)

40. Gartner: Number of smartphones sold to end users worldwide from 2007 to 2017 (in million units). https://www.statista.com/statistics/263437/global-smartphone-sales-to-end-userssince-2007/. Accessed 23 Jan 2019

Open Access This chapter is distributed under the terms of the Creative Commons Attribution 4.0 International License (http://creativecommons.org/licenses/by/4.0/), which permits use, duplication, adaptation, distribution and reproduction in any medium or format, as long as you give appropriate credit to the original author(s) and the source, a link is provided to the Creative Commons license and any changes made are indicated.

The images or other third party material in this chapter are included in the work's Creative Commons license, unless indicated otherwise in the credit line; if such material is not included in the work's Creative Commons license and the respective action is not permitted by statutory regulation, users will need to obtain permission from the license holder to duplicate, adapt or reproduce the material. 